\title{
A Rare Case of Bruck Syndrome Type 2 in Siblings With Broad Phenotypic Variability
}

\author{
Lindsey Luce, MBBS, ${ }^{1}$ Michael Casale, $\mathrm{MD}^{2,3}$ Sean Waldron, $\mathrm{MD}^{2,3}$ \\ ${ }^{1}$ Department of Orthopedic Surgery, Medical University of South Carolina, Charleston, SC ${ }^{2}$ Department of Orthopedic Surgery, Ochsner \\ Clinic Foundation, New Orleans, LA ${ }^{3}$ The University of Queensland Faculty of Medicine, Ochsner Clinical School, New Orleans, LA
}

Background: Bruck syndrome is a rare autosomal recessive condition that presents with many of the symptoms of osteogenesis imperfecta. In addition to defective type I collagen, manifesting as bone fragility, osteoporosis, and blue sclera, Bruck syndrome is additionally characterized by arthrogryposis with pterygia. Joint contractures are frequently bilateral and severe.

Case Report: We report the medical record and radiographic data for 2 siblings with Bruck syndrome type 2-a male (age 6 years) and a female (age 5 years) - born to nonaffected parents. The male has experienced more than 45 fractures, developed severe scoliosis, and has debilitating flexion contractures. The female has minimal flexion contractures, a history of 15 fractures, and severe scoliosis.

Conclusion: The dramatic difference between the phenotypes of these 2 cases is significant because it is the largest known variability of phenotypic presentation in siblings. Previous cases of siblings with differing presentations at birth have been reported, but the extent of these differences is not as extreme as in our cases. Because Bruck syndrome presents similarly to osteogenesis imperfecta and could be clinically mistaken for a form of osteogenesis imperfecta if contractures are minimal, a reasonable focus for research efforts is the development of genetic diagnostic protocols for osteogenesis imperfecta with the goal of ruling out Bruck syndrome.

Keywords: Bruck syndrome 2, scoliosis, pediatrics

Address correspondence to Sean Waldron, MD, Department of Orthopedic Surgery, Ochsner Clinic Foundation, 1514 Jefferson Hwy., New Orleans, LA 70121. Tel: (504) 842-3970. Email: sean.waldron@ochsner.org

\section{INTRODUCTION}

Osteogenesis imperfecta is a primarily autosomal dominant disorder involving defective type I collagen that manifests as bone fragility, osteoporosis, blue sclera, and hearing loss. ${ }^{1}$ Bruck syndrome is a rare collagen disorder that presents with all of these symptoms of osteogenesis imperfecta, excluding hearing loss, and is additionally characterized by arthrogryposis with pterygia. ${ }^{1,2}$ Joint contractures are frequently bilateral and severe. ${ }^{2}$

Bruck syndrome occurs in multiple types, with the distinguishing factor being the collagen gene in which a mutation has occurred. Bruck syndrome types 1 and 2 are the most common forms, involving mutations of the FKBP10 and PLOD2 collagen genes, respectively. ${ }^{1,3}$ There are no known phenotypic differences between types 1 and 2.,4 Inheritance patterns for all types of Bruck syndrome have been described as autosomal recessive. ${ }^{2,5}$ Bruck syndrome, like osteogenesis imperfecta, is not known to be associated with any language or cognitive developmental milestone delays. We present the cases of 2 siblings who both have Bruck syndrome but who presented with markedly different phenotypic pictures.

\section{CASE REPORT}

The mother of the 2 children has no known collagen disorder or other genetic condition. The father also has no known collagen disorder; however, he has a mildly abnormally shaped skull with a questionable history of premature sagittal suture closure in infancy.

\section{Male Sibling}

The older child is a 6-year-old male who presented at birth with generalized hypotonia, plagiocephaly, flexion contractures of the knees and ankles, left talipes equinovarus, right vertical talus, torticollis, multiple rib fractures, and a left clavicle fracture. He was born via caesarean section because of breech position. He was born preterm at 36 weeks, but the pregnancy was otherwise uncomplicated. He has met all language and cognitive developmental milestones to date. Genotyping revealed a mutation of the PLOD2 gene, consistent with Bruck syndrome type 2.

He has generalized upper extremity hypotonia with poor truncal control. His skull has normalized since birth, but he remains mildly deformed with plagiocephaly and frontal bossing. He underwent bilateral serial casting followed by 


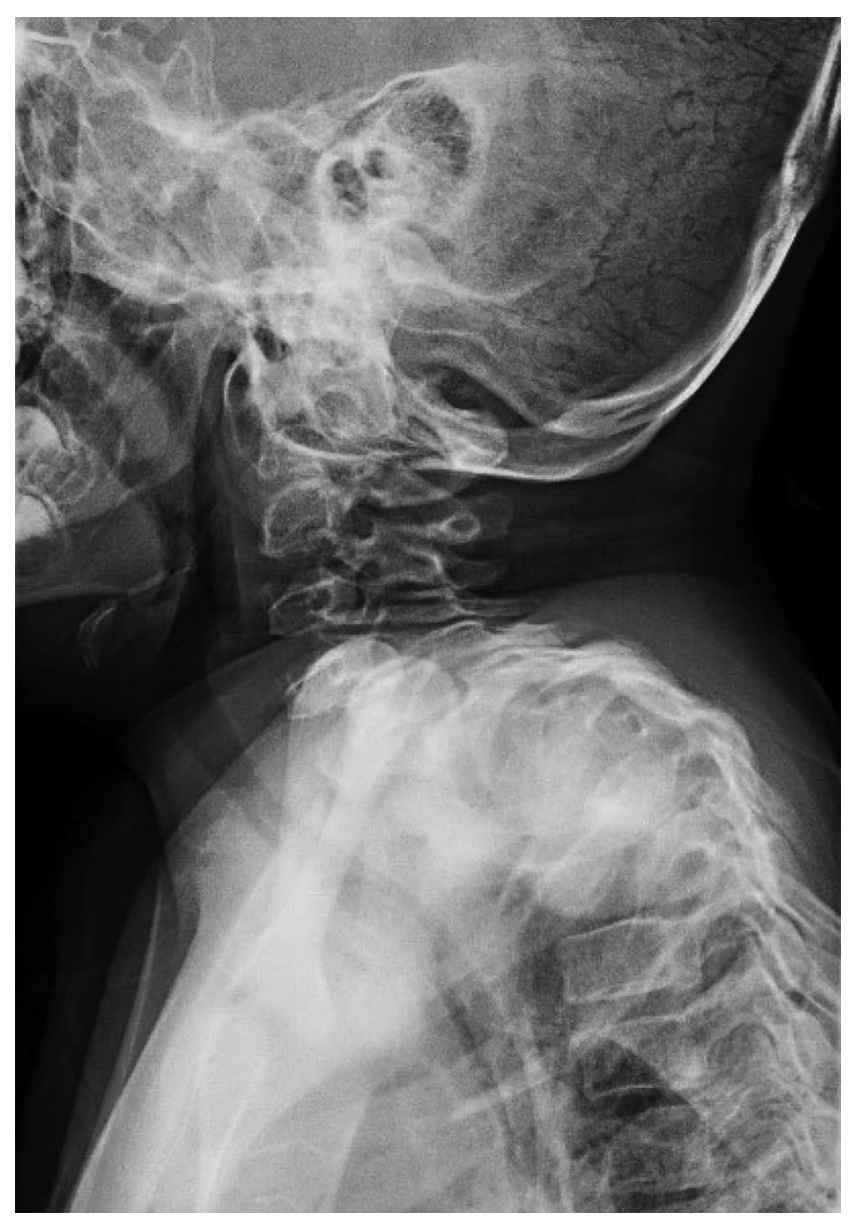

Figure 1. Radiograph of cervical and thoracic spine of the male sibling at age 4 showing severe spinal deformity.

serial knee-ankle-foot orthotic (KAFO), bracing for attempted correction of his knee and ankle flexion deformity from age 3 months until 2 years of age. Repeated bilateral Achilles and hamstring tenotomies have also been performed. Despite this management, he continues to have severe bilateral knee and ankle joint contractures. By age 3 , he developed severe cervicothoracic scoliosis (Figure 1) consisting of a complex segmentation anomaly from the $\mathrm{C} 6$ to the T1 vertebra, resulting in severe levoscoliosis of the cervicothoracic spine. He underwent posterior fusion of C2 to T6 in 2014 at the age of 5 (Figure 2).

To date, he has a history of more than 45 fractures, with many requiring either intramedullary nailing or open reduction with internal fixation. His left femur has been the most frequently affected by the condition, with at least 5 fractures and significant deformity occurring as a result (Figure 3). Because of this deformity and severe joint contractures affecting his bilateral hips, knees, and ankles, the child is unable to walk and only able to weight bear for short periods of time. His treatment plan includes the implantation of a telescoping nail to correct the deformity of his left femur.

His spine bone mineral density (BMD) at age 6 is $0.459 \mathrm{~g} / \mathrm{cm}^{2}$, giving him an age-matched Z-score of -2.3 . $\mathrm{He}$ has consistently been measured at less than the first percentile for height with respect to age and sex since turning 5 years old. In addition to the aforementioned treatments, he

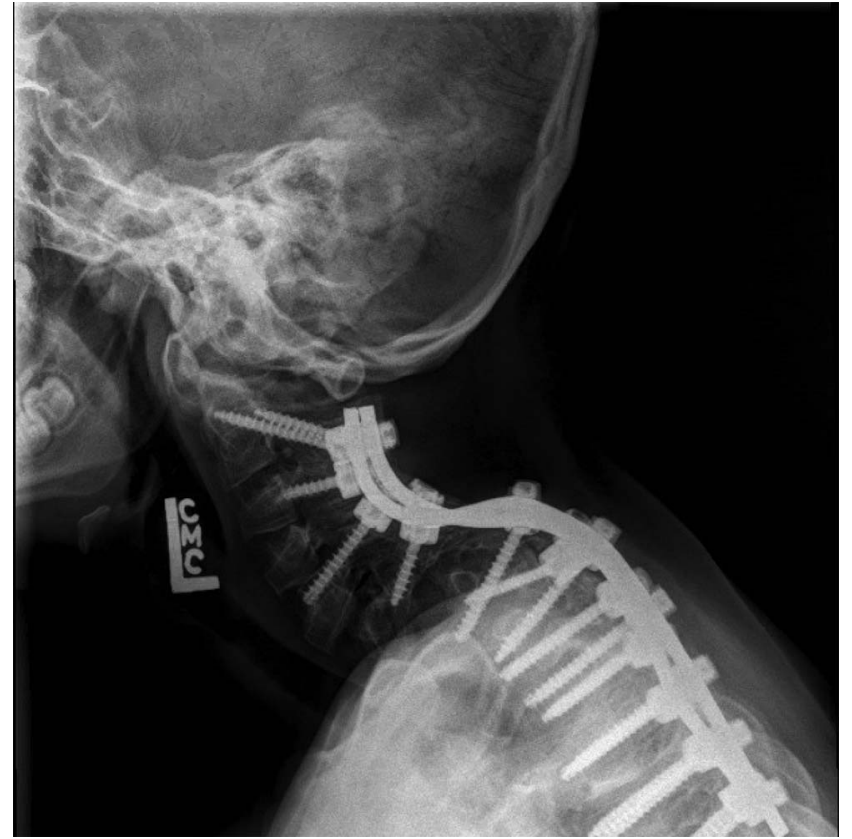

Figure 2. Lateral radiograph of cervical spine of the male sibling after undergoing posterior spinal fusion for scoliosis at age 5.

has been managed with physical therapy for serial stretching to increase joint mobility, regular pamidronate infusions, and vitamin $\mathrm{D}$ and calcium supplementation. At present, he requires full-time care and assistance and will continue to do so in the future.

\section{Female Sibling}

The younger child is a 5-year-old female who presented at birth with frontal bossing, micrognathia, a low-set right ear, and multiple rib fractures. She had no contractures or extremity fractures at birth. She was born via caesarean section at term after an uncomplicated pregnancy. She has met all language and cognitive milestones to date. PLOD2 gene testing revealed the same mutation as her brother, giving her a diagnosis of Bruck syndrome type 2 .

She has persistent midface hypoplasia and micrognathia. She has developed severe thoracic levoscoliosis with anterior wedging of the T7 and T10 vertebrae and autofusion in her thoracic spine that was first noticeable at age 4 (Figure 4). Her scoliosis is progressively worsening with growth; she has yet to undergo correction. She also has congenital malformation of the left shoulder consisting of an abnormally shaped and hypoplastic clavicle, scapula, and proximal humerus (Figure 5).

To date, she has had approximately 15 known fractures, none of which have required operative treatment. She has minimal lower extremity joint contractures and is able to walk with a walker, although walking is becoming more difficult with the progression of her scoliosis.

Her spine BMD at age 5 is $0.342 \mathrm{~g} / \mathrm{cm}^{2}$, giving her an agematched Z-score of -3.1 . In comparison to her brother (less than first percentile after age 5), her short stature is less severe, measuring at the first to fifth percentile for height with respect to age and sex. To date, her medical treatment 


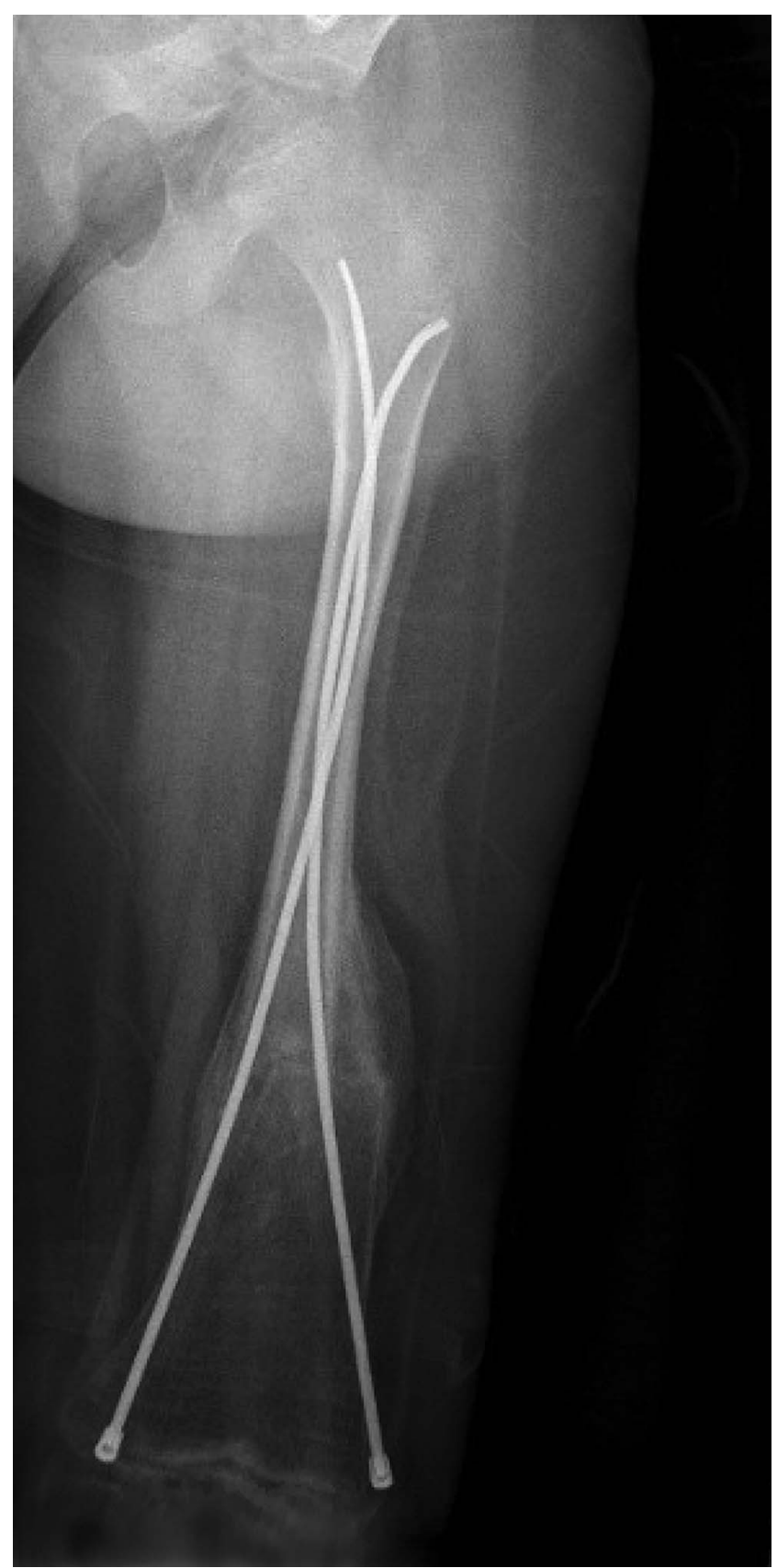

Figure 3. Radiograph of left femur of the male sibling showing a healed femur fracture after intramedullary nailing at age 4.

has also consisted of physical therapy for serial stretching, regular pamidronate infusions, and vitamin $D$ and calcium supplementations. Ultimately, this patient will require spinal fusion surgery to correct her scoliosis and hopefully maintain her ability to ambulate.

\section{DISCUSSION}

The phenotypic differences between the 2 siblings are summarized in the Table. Phenotypic variability has been widely evident in Bruck syndrome, most notably in reports of siblings with the disease. ${ }^{6,7}$ Variability appears to exist with respect to the extent of bone fragility, as well as both the

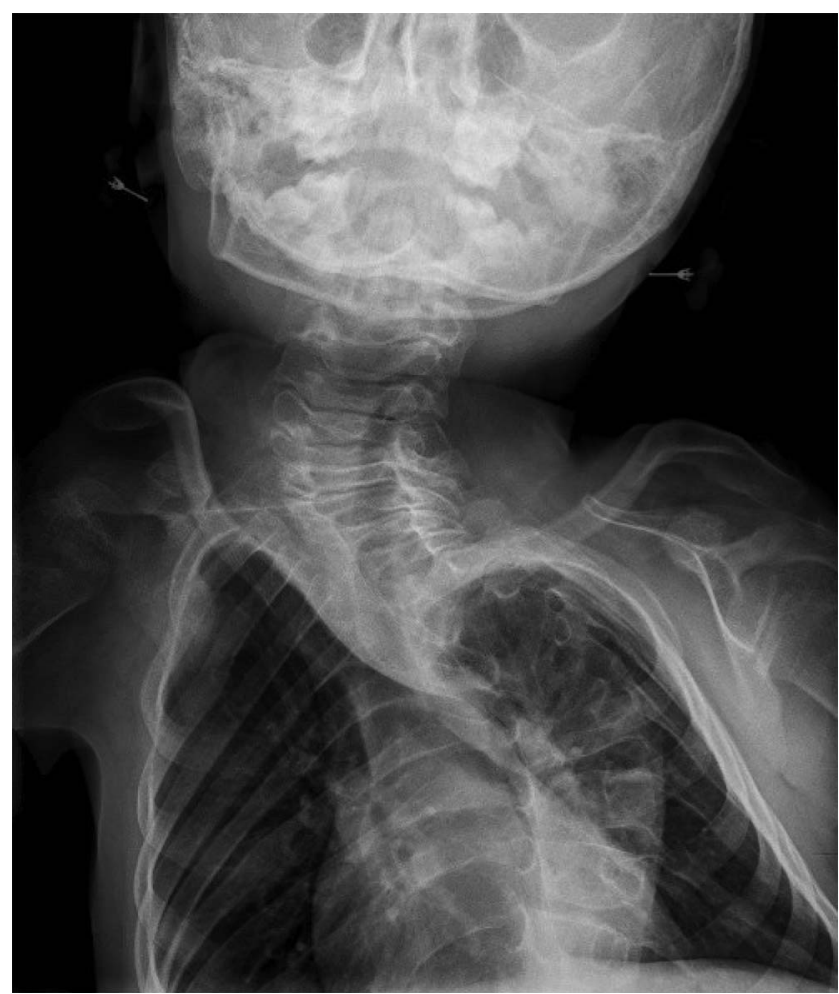

Figure 4. Radiograph of cervical and thoracic spine of the female sibling at age 5 showing severe spinal deformity and autofusion.

severity and prevalence of contractures. Multiple joint contractures have been the defining characteristic of Bruck syndrome since its first description in 1897.2,8 Arthrogryposis remains the primary characteristic of Bruck syndrome that distinguishes it from osteogenesis imperfecta.

Bruck syndrome tends to have a worse prognosis than osteogenesis imperfecta because the multiple joint contractures complicate functional ability and fracture healing. In patients with cerebral palsy, multiple joint contractures have been well documented to increase the fracture rate and to complicate fracture healing. ${ }^{9}$ Patients with a more severe contracture phenotype have decreased functional capacity at baseline, such as in the case of the male child. In

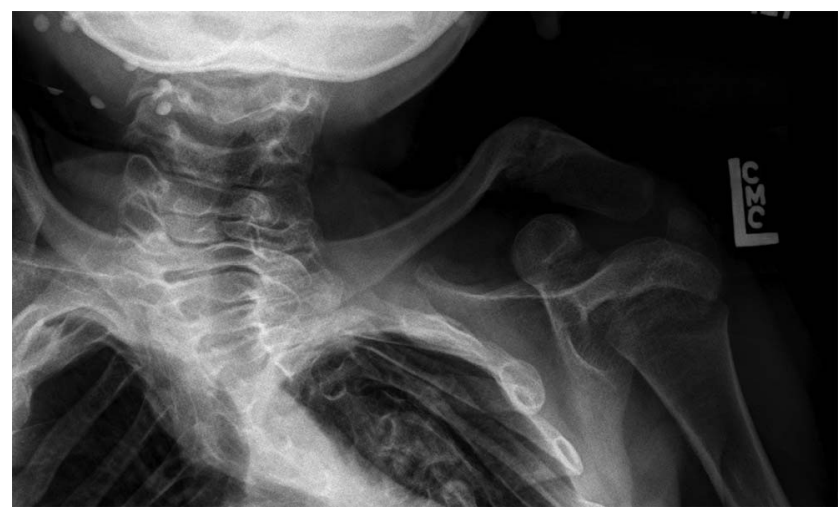

Figure 5. Radiograph of the left shoulder girdle of the female sibling at age 5 showing abnormally shaped and hypoplastic clavicle, scapula, and proximal humerus. 


\begin{tabular}{|c|c|c|c|c|}
\hline \multirow[b]{2}{*}{ Phenotype } & \multicolumn{2}{|c|}{ Male, Age 6 years } & \multicolumn{2}{|c|}{ Female, Age 5 years } \\
\hline & Description & $\begin{array}{c}\text { Age of } \\
\text { Onset/Progression }\end{array}$ & Description & $\begin{array}{c}\text { Age of } \\
\text { Onset/Progression }\end{array}$ \\
\hline \multirow[t]{2}{*}{ Contractures } & $\begin{array}{l}\text { Severe flexion } \\
\text { contractures of knee } \\
\text { and ankle joints, } \\
\text { bilaterally }\end{array}$ & $\begin{array}{l}\text { Birth/Persistent but less } \\
\text { severe after multiple } \\
\text { tenotomies }\end{array}$ & $\begin{array}{l}\text { No lower extremity } \\
\text { contractures at } \\
\text { birth }\end{array}$ & $\mathrm{N} / \mathrm{A}$ \\
\hline & $\begin{array}{l}\text { No upper extremity joint } \\
\text { contractures }\end{array}$ & $\mathrm{N} / \mathrm{A}$ & $\begin{array}{l}\text { No upper extremity } \\
\text { joint contractures }\end{array}$ & N/A \\
\hline Fractures & More than 45 fractures & $\begin{array}{l}\text { Left clavicle and multiple } \\
\text { rib fractures at } \\
\text { birth/Persistent in } \\
\text { frequency; many open } \\
\text { reductions required }\end{array}$ & $\begin{array}{l}\text { Approximately } 15 \\
\text { fractures }\end{array}$ & $\begin{array}{l}\text { Rib fractures present at } \\
\text { birth/No open } \\
\text { reductions required }\end{array}$ \\
\hline Spinal deformities & $\begin{array}{l}\text { Severe cervicothoracic } \\
\text { scoliosis, complex } \\
\text { segmentation anomaly } \\
\text { C6-T1 }\end{array}$ & $\begin{array}{l}\text { Severe status by age 3/ } \\
\text { Spinal fusion at age } 5\end{array}$ & $\begin{array}{l}\text { Moderate thoracic } \\
\text { scoliosis, wedging } \\
\text { of T7 and T10 }\end{array}$ & $\begin{array}{l}\text { Severe status by age 4/ } \\
\text { Yet to undergo } \\
\text { correction }\end{array}$ \\
\hline $\begin{array}{c}\text { Skull and facial } \\
\text { deformities }\end{array}$ & $\begin{array}{l}\text { Plagiocephaly, frontal } \\
\text { bossing, bilateral } \\
\text { proptosis, wormian } \\
\text { bones }\end{array}$ & $\begin{array}{l}\text { Birth/Normalized to mild } \\
\text { deformity since birth }\end{array}$ & $\begin{array}{l}\text { Midface hypoplasia, } \\
\text { micrognathia }\end{array}$ & Birth/Persistent \\
\hline Height for age, sex & Less than first percentile & Age 6 years & $\begin{array}{l}\text { Between first and fifth } \\
\text { percentiles }\end{array}$ & Age 5 years \\
\hline $\begin{array}{l}\text { Bone mineral } \\
\text { density }\end{array}$ & $\begin{array}{l}0.459 \mathrm{~g} / \mathrm{cm}^{2} \\
\text { Age-matched Z-score of } \\
-2.3\end{array}$ & Age 6 years & $\begin{array}{l}0.342 \mathrm{~g} / \mathrm{cm}^{2} \\
\text { Age-matched Z-score } \\
\text { of }-3.1\end{array}$ & Age 5 years \\
\hline $\begin{array}{l}\text { Weight-bearing } \\
\text { status }\end{array}$ & $\begin{array}{l}\text { Pulls to stand, unable to } \\
\text { walk }\end{array}$ & Persistent & $\begin{array}{l}\text { Pulls to stand, walks } \\
\text { with aid }\end{array}$ & $\begin{array}{l}\text { Ability to walk decreasing } \\
\text { with progression of } \\
\text { scoliosis }\end{array}$ \\
\hline \multirow[t]{2}{*}{ Other } & $\begin{array}{l}\text { Left talipes equinovarus, } \\
\text { right vertical talus }\end{array}$ & $\begin{array}{l}\text { Birth/Only moderately } \\
\text { improved despite } \\
\text { serial KAFO bracing, } \\
\text { Achilles tenotomies }\end{array}$ & $\begin{array}{l}\text { No foot/ankle } \\
\text { deformity }\end{array}$ & $\mathrm{N} / \mathrm{A}$ \\
\hline & $\begin{array}{l}\text { No shoulder/upper } \\
\text { extremity deformity }\end{array}$ & $\mathrm{N} / \mathrm{A}$ & $\begin{array}{l}\text { Misshapen and small } \\
\text { clavicle, scapula, } \\
\text { and proximal } \\
\text { humerus }\end{array}$ & Birth \\
\hline
\end{tabular}

KAFO, knee-ankle-foot orthotic; N/A, not applicable.

contrast to his younger sister, he has been managed with multiple lower extremity tenotomies, yet he is unable to walk because of the postoperative recurrence of contractures and fracture-induced deformities. The younger sister has had far fewer fractures and less severe short stature than her brother despite her lower spine BMD.

The dramatic difference between the phenotypes of these 2 cases is significant in that it represents the largest variability of phenotypic presentation in siblings that is known to the authors. Previous cases of siblings having differing presentations at birth, tendencies toward fracture, severities of contractures, and functional capacities have been reported; however, the extent of these differences is not as extreme as in the siblings presented here. ${ }^{6}$
Given the rarity of Bruck syndrome, no major efforts to develop treatment options for the disease have been undertaken that are distinct from the efforts for osteogenesis imperfecta. The current nonoperative treatment modalities are nearly identical to those used for osteogenesis imperfecta and consist of regular bisphosphonate infusions and vitamin supplementation. These treatments have been proven to be effective for both disease processes; however, the prognosis for Bruck syndrome is more severe given the complications of joint contractures. ${ }^{10}$

When joint contractures are not pronounced, distinguishing between Bruck syndrome and osteogenesis imperfecta without genotyping may be difficult, as the fracture patterns on radiographic imaging and the physical 
examination may be congruous. Both autosomal recessive and autosomal dominant inheritance patterns have been described for osteogenesis imperfecta, and distinguishing Bruck syndrome from the rare autosomal recessive subtype of osteogenesis imperfecta may be difficult, as multiple loci on the FKBP10 and PLOD2 genes have been implicated in both disease processes. ${ }^{1,3,5}$ Thus, more specific genetic analysis may be necessary to delineate between these diseases if the existence of joint contractures is minimal.

Because Bruck syndrome presents similarly to osteogenesis imperfecta and could be clinically mistaken for a form of osteogenesis imperfecta if contractures are minimal, a reasonable focus for research efforts is genetic diagnostic protocols for osteogenesis imperfecta with the goal of ruling out Bruck syndrome. Such protocol development would be beneficial for families and physicians as early genetic analysis and pedigree assessment are essential for accurate diagnosis and prognostication for individuals and the future offspring of affected families.

\section{CONCLUSION}

These siblings demonstrate dramatic differences in phenotypes representative of Bruck syndrome. Future research aimed at distinguishing between osteogenesis imperfecta and Bruck syndrome at the genetic level will be key for diagnostic and prognostic purposes, as the presence of severe joint contractures drastically changes the treatment and outcomes of patients with Bruck syndrome compared to patients with osteogenesis imperfecta alone.

\section{ACKNOWLEDGMENTS}

The authors have no financial or proprietary interest in the subject matter of this article.

\section{REFERENCES}

1. Kelley BP, Malfait F, Bonafe $L$, et al. Mutations in FKBP10 cause recessive osteogenesis imperfecta and Bruck syndrome. J Bone Miner Res. 2011 Mar;26(3):666-672. doi: 10.1002/jbmr.250.
2. Breslau-Siderius EJ, Engelbert RH, Pals G, van der Sluijs JA. Bruck syndrome: a rare combination of bone fragility and multiple congenital joint contractures. J Pediatr Orthop B. 1998 Jan;7(1):35-38. doi: 10.1097/01202412-199801000-00006.

3. Schwarze U, Cundy T, Pyott SM, et al. Mutations in FKBP10, which result in Bruck syndrome and recessive forms of osteogenesis imperfecta, inhibit the hydroxylation of telopeptide lysines in bone collagen. Hum Mol Genet. 2013 Jan 1;22(1):1-17. doi: 10.1093/hmg/dds371.

4. Ha-Vinh R, Alanay Y, Bank RA, et al. Phenotypic and molecular characterization of Bruck syndrome (osteogenesis imperfecta with contractures of the large joints) caused by a recessive mutation in PLOD2. Am J Med Genet A. 2004 Dec 1;131(2):115-120. doi: 10.1002/ajmg.a.30231.

5. Puig-Hervás MT, Temtamy S, Aglan M, et al. Mutations in PLOD2 cause autosomal-recessive connective tissue disorders within the Bruck syndrome-osteogenesis imperfecta phenotypic spectrum. Hum Mutat. 2012 Oct;33(10):1444-1449. doi: 10.1002/humu.22133.

6. Shaheen R, Al-Owain M, Faqeih E, et al. Mutations in FKBP10 cause both Bruck syndrome and isolated osteogenesis imperfecta in humans. Am J Med Genet A. 2011 Jun;155A(6):1448-1452. doi: 10.1002/ajmg.a.34025.

7. Mokete L, Robertson A, Viljoen D, Beighton P. Bruck syndrome: congenital joint contractures with bone fragility. J Orthop Sci. 2005 Nov;10(6):641-646. doi: 10.1007/s00776-005-0958-9.

8. Blacksin MF, Pletcher BA, David M. Osteogenesis imperfecta with joint contractures: Bruck syndrome. Pediatr Radiol. 1998 Feb;28(2):117-119. doi: 10.1007/s002470050309.

9. Mughal MZ. Fractures in children with cerebral palsy. Curr Osteoporos Rep. 2014 Sep;12(3):313-318. doi: 10.1007/s11914-014-0224-1.

10. Otaify GA, Aglan MS, Ibrahim MM, Elnashar M, El Banna RA, Temtamy SA. Zoledronic acid in children with osteogenesis imperfecta and Bruck syndrome: a 2-year prospective observational study. Osteoporos Int. 2016 Jan;27(1):81-92. doi: 10.1007/s00198-015-3216-9.

This article meets the Accreditation Council for Graduate Medical Education and the American Board of Medical Specialties Maintenance of Certification competencies for Patient Care and Medical Knowledge.

(C)2020 by the author(s); licensee Ochsner Journal, Ochsner Clinic Foundation, New Orleans, LA. This article is an open (C) (i) access article distributed under the terms and conditions of the Creative Commons Attribution (CC BY) license (creativecommons.org/licenses/by/4.0/legalcode) that permits unrestricted use, distribution, and reproduction in any medium, provided the original author(s) and source are credited. 